\title{
Measurement and Analysis of Vibrations of the Axial - Flow Compressor Coused by Inlet Flow Instability During the Flight of Aircraft
}

\author{
Dragana Žakić Nedeljković ${ }^{1)}$ \\ Aleksandar Simonović ${ }^{2)}$ \\ Slobodan Stupar $\left.{ }^{2}\right)$ \\ Nebojša Lukić ${ }^{1)}$
}

\begin{abstract}
This paper presents a practical example of the measurement and analysis of vibrations in the first two stages of the axial-flow compressor with intention to estimate a connection between inlet air flow distortions and appearance of stalling of the compressor blades. The inlet air flow distortions were tested during different regimes of the aircraft flight with a maximum thrust, with an assumption that the asymmetry of air flow through the twin-inlets existed and had effect on vibrations of the compressor. The paper shows the measurement of vibrations on the Galeb G-2 aircraft powered by the Rolls Royce Viper Mk22-6 engine with the aim to recognize and define the minimum necessary data for detection of the potential distorted air flow through the compressor, as concequences of an unequal air flow distribution in the inlets. The detection capability of this methodology of measurement is presented using the fast Fourier transform (FFT). The proposed methodology of measurement and analysis can be implemented in different types of aircraft in order to research the occurrence of stall and surge.
\end{abstract}

Key words: aircraft engine, jet engine, axial-flow compressor, air flow, vibration, vibration measurement, blades stalling, flight test.

\section{Introduction}

$\mathrm{O}$ VER the past several decades a lot of attention has been devoted to the study of air flow through a turbojet engine, because when the turbojet engine operates close to its optimal operating parameter values (max efficiency), the air flow through the compressor can become unstable [1].

These instabilities put a large stress on the engine and they can lead to the appearance of vibration and engine damage. There are primarily two types of instabilities that occur in the flow through the compressor: surge and stall [2]. Surge is described by large oscillations of the mean mass flow through the engine, that may become reversed, pushing the air back on the front of the engine. This leads to a large stress on the engine components and seriously distorts its performance. A decrease in the mass flow rate, an increase in the rotational speed of the impeller, or both, can cause the compressor to surge.

The surge should not be confused with the phenomenon of stalling of a compressor stage. Stalling is the break away of the flow from the suction side of the blade aerofoil. Causes may be due to a too high angle of attack at the leading edge of the blades. A multi-stage compressor may operate stably in the unsorted region with one or more of the stages stalled, and the rest of the stages uninstalled.

One should note that the operating at a higher efficiency implies operation closer to surge.

Reid [3] considered the influence of the intake flow distortion to the axial flow compressors and concluded as a design speed of the compressor was approached, the loss of surge pressure ratio, due to the inlet flow mal-distribution, was mainly dependent on the circumferential variation of the inlet total pressure.

These instabilities of the inlet flow total pressure can be due to any one of many different effects like a break-away from the intake edge at high angles of attack, break-away from walls of curved inlet ducts, ingestion of boundary layers, etc. In military engines, due to the extreme flight conditions, the extent of this phenomenon is increased.

Ghisu at al. [4] had tested different types of distortion on a specially designed compressor (different types of inlet total pressure distortions were simulated). They found that the main effect was the drop of the axial velocity of the flow in the distorted region. This drop leads to the change of some of the global parameters that usually describe the performance of a compressor, such as mass flow, pressure ratio and efficiency. All the different effects are inter-related: the decrease in axial velocity changes the direction of the flow relative to the rotating blade [5], increasing the load on the blade and moving the operating point towards the surge line.

One of the research papers explains that uneven air flow distribution produced by layers of screen in one of the twin inlets, at a high altitude, may have been indicating compressor to operate in stall although the engine operation as a whole was stable [6]. An investigation was made to determine the effects on turbojet engine performance of unequal air flow distribution through simulated inlet ducts and find that the division in the air flow resulted in a discontinuous of the total pressure at the compressor inlet and furthermore, had the

\footnotetext{
1) Technical Test Center, Vojvode Stepe 445, 11000 Belgrade, SERBIA

2) University of Belgrade, Faculty of Mechanical Engineering, Kraljice Marije 16, 11120 Belgrade 35, SERBIA

Correspondence to: Dragana Žakić Nedeljkovic, email: dragana108@yahoo.com
} 
effect on compressor blade vibration and compressor rotating stall $[7,8]$.

Thorough research was carried out on an engine test bench by exploring stress amplitudes for rotor blade, stress in rotor blade, free inlet flow acceleration, vibration amplitudes, asynchronous vibrations, which have shown the highest levels of the rotor blade stress occur at resonance frequencies and during unsteady compressor operating conditions. These conditions include aerodynamic instability caused by rotating stall zones and compressor surges $[9,10]$. From the reasons in this paper, among others, the compressor blade stress will be analyzed as a relevant factor when it comes to unstable air flow, in real flight conditions.

This paper presents the measurement of vibrations on a Galeb G-2 aircraft powered by the Rolls Royce Viper Mk22-6 engine with the aim to recognize and define the minimum necessary data for the detection of potential distorted air flow through the compressor, as consequences of the unequal distribution air flow in inlet. The fault detection capability of this method will be presented using the fast Fourier transform (FFT) of the time domain signal and the pass in the frequency domain [11].

\section{Stress on the axial-flow compressor blade}

Since the research was carried out in extreme flight conditions, at the maximum engine RPM (revolution per minute), during the analysis of vibration we must look back at stresses that can occur in this case.

During the turbojet engine operation, stresses that occur in the blades of axial-flow compressor are tension, bending and torsional stress due to the centrifugal force of its own masses and the gas-dynamic forces acting of the blades.

Also, there are additional oscillatory stresses of bending and torsion. For the first stages of the compressor, the highest values have a tension stresses from centrifugal forces.

The centrifugal force of an infinitely small element is:

$$
\partial P=\rho \omega^{2} F R \partial R
$$

where:

$\rho$ - blades material density,

$\omega$ - the angular velocity of rotation,

$F$ - cross-sectional surface of the blade,

$R$ - the distance of the observed surface from the rotation axis. The centrifugal force is:

$$
P=\rho \omega^{2} \int_{R}^{R_{2}} F R \partial R
$$

where:

$R_{2}$ - the distance of the top of the blade from the rotation axis.

The tension stress, $\sigma_{R}$, in the cross section which is located at the distance $R$ from the axis of rotation is:

$$
\sigma_{R}=P / F=\rho \omega^{2}\left(R_{2}^{2}-R^{2}\right) / 2
$$

The maximum tension stress occurs in the root and its value is obtained from:

$$
\sigma_{R}=\sigma_{\max }=\rho \omega^{2}\left(R_{2}^{2}-R_{1}^{2}\right) / 2 ; F=\text { const } .
$$

where:

$R_{1}$ - the distance of the root of the blade from the rotation axis. If the cross-sectional surface changes according to the law

$$
F=F_{r}-a l^{q}
$$

where:
$F_{r}$ - cross-sectional surface of the blade root,

$a$ - coefficient of proportionality,

$l$ - variable coordinate along the axis of the blades and dimensionless coefficient $q=1$ for linear law changes on the surface, the tension stress in the root is:

$$
\sigma_{R}=\frac{\rho u^{2} l_{p}}{R_{m}}\left[1-\left(1-F_{t} / F_{r}\right)\left(\frac{1}{\left(1+R_{2} / R_{1}\right)}+\frac{l_{p}}{3 R_{m}}\right)\right]
$$

where:

$l_{p}$ - total height of the blade,

$F_{t}$ - cross-sectional surface of the blade top, $R_{m}=\left(R_{1}+R_{2}\right) / 2$ and $u^{2}=R_{m}{ }^{2} \omega^{2}$.

When $q=0,5-0,6$, the tension stress in the root is lower than (6), and $\sigma_{\max }$ appears in the cross-section area above the root.

Allowed tension stresses in the blades of the axial-flow compressors, reach the following values:

- for steel blades (3000-3500) $10^{5} \mathrm{~Pa}$

- for aluminum alloy blades $(1000-1500) 10^{5} \mathrm{~Pa}$

- for titan alloy blades (1500-2000) $10^{5} \mathrm{~Pa}$

For determining bending stress on the compressor blades from the gas-dynamic and centrifugal forces, it is necessary to find a resistant bending torque, using point coordinates and torques of inertia.

Bending stress for the blade at the characteristic points, from gas-dynamic forces is:

$$
\sigma_{p i}=\frac{M_{p \xi}}{J_{\xi}} \eta_{i}+\frac{M_{p \eta}}{J_{\eta}} \xi_{i}
$$

and from the centrifugal forces

$$
\sigma_{j i}=-\frac{M_{j \xi}}{J_{\xi}} \eta_{i}-\frac{M_{j \eta}}{J_{\eta}} \xi_{i}
$$

where:

$M_{p \xi}, M_{j \xi}, M_{p \eta}, M_{j \eta}$ - the components of the bending moments along the main inertia axes from gas-dynamic and centrifugal forces,

$\eta, \xi$ - the point coordinates, $J_{\xi}, J_{\eta}$ - torques of inertia.

Maximum allowed bending stress from gas-dynamic forces, for the first stage blades of the axial-flow compressor, can reach from 50 to $120 \mathrm{MPa}$ [12].

The overall stress at some point of the cross-sectional blade surface is the sum of the bending and tension stresses.

$$
\sigma_{\Sigma i}=\sigma_{p i}+\sigma_{j i}+\sigma_{R}
$$

The allowed overall stresses in the blades of the axial-flow compressors, reach the following values:

- for steel blades (3000-3500) $10^{5} \mathrm{~Pa}$

- for aluminum alloy blades $(1500-2300) 10^{5} \mathrm{~Pa}$

- for titan alloy blades (2000-2500)105 $\mathrm{Pa}$

Bending stress of gas-dynamic and the centrifugal forces is required to be calculated separately because the bending stress from the gas-dynamic forces are sometimes used as a criterion for the stresses caused by the blades oscillation.

The torsion stress from mentioned forces are low and, during the calculation of the strength of blades, are usually ignored [12].

The mentioned forces are changing with the air flow, therefore it is advisable to do calculations or monitoring of strength for dangerous regimes, as a regime with maximum flow of air through the engine and maximum RPM.

All the stresses depend on distribution uniformity of the air 
flow inlet pressure in front of the compressor. This paper will consider experimental research of the unstable air flow through the inlet and discuss the causes that may lead to that and disrupt smooth operation of the compressor.

\section{Measurement of vibration at axial flow compressor during the flight}

Flight tests were conducted on a single engine, two-seater advanced jet trainer Galeb G-2. The aircraft is equipped with the Rolls Royce, Viper Mk 22-6 turbojet engine, with the maximum thrust of $11.12 \mathrm{kN}$. The engine was designed with seven stages axial compressor and one stage of turbine. The maximum engine speed (RPM) is $n=13800 \mathrm{~min}^{-1}$ or $230 \mathrm{~Hz}$. The each compressor stage has a different number of blades. The number of blades for each compressor stage and their corresponding frequencies are given in Table 1.

Table 1. Number of compressor blades and their frequencies at the maximum engine speed

\begin{tabular}{||ccc|}
\hline Stage & Number of blades & Working frequency $(\mathrm{Hz})$ \\
\hline \hline $1^{\text {st }}$ & 24 & 5520 \\
\hline $2^{\text {nd }}$ & 25 & 5750 \\
\hline $3^{\text {rd }}$ & 37 & 8510 \\
\hline $4^{\text {th }}$ & 51 & 11730 \\
\hline $5^{\text {th }}$ & 74 & 17020 \\
\hline $6^{\text {th }}$ & 71 & 16330 \\
\hline $7^{\text {th }}$ & 72 & 16560 \\
\hline
\end{tabular}

Vibration measuring has been realized with a multichannel digital system NetdB12-01 Metravib. This is a multichannel digital system for measurements of vibrations and noise which has an internal battery power and a recorder. It is equipped with a dBFA Suite dedicated software for data processing in real time. The device is equipped with the dBFA Suite utility software for collecting and processing data in real time.

For vibration measurements the $\mathrm{B} \& \mathrm{~K}$ uniaxial piezo accelerometers, type 4383P, were used. The recording configuration was equipped with two accelerometers on the first stage compressor positions, given in Fig.1. Those accelerometers were used to measure the acceleration as a vibration amplitude along the radial and tangential directions.

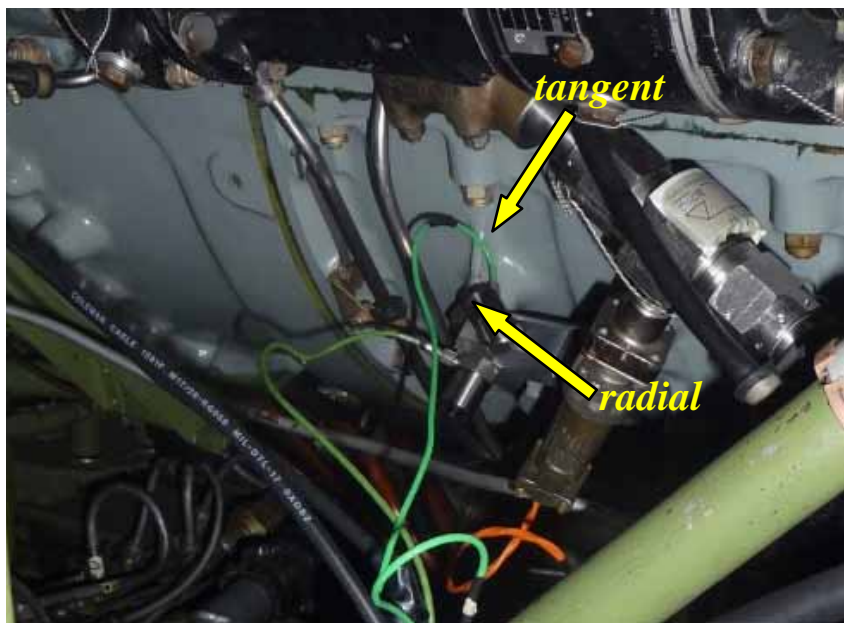

Figure 1. The accelerometers installed on the specific locations on the engine

For acquisition data from sensors and probe during the flight testing the DAMIAN multi-function airborne acquisition system was used. For this kind of testing it was necessary to measure the following parameters of flight: altitude $\left(H_{i}\right)$, airspeed $\left(V_{i}\right)$, pitch $(\theta)$, roll $(\phi)$, yaw $(\psi)$, normal acceleration in direction of main axis $\left(N_{X}, N_{Y}, N_{Z}\right)$, angular velocities $\left(\omega_{X}, \omega_{Y}, \omega_{Z}\right)$, etc...

During the preparation for experiments the time synchronization between the DAMIAN device was performed with the acquisition systems NetdB12 - 01Metravib.

The vibration characteristics of the engine compressor blades were determinated in different flight regimes. In this paper the three specific regimes will be presented. The regimes have requested $100 \%$ engine RPM at the following conditions:

- Best climb at altitude $\mathrm{Hi}=2500 \mathrm{~m}$,

- Acceleration at altitude $\mathrm{Hi}=2000 \mathrm{~m}$,

- Climbing turn.

\section{Test results}

The experiment was conducted in the aircraft flight modes which require maximum engine thrust.

Selected flight modes are: take-off and climb, horizontal flight and climbing turn. All three regimes demand a different position of the airplane relative to the ground.

The reason for measuring the vibration in these modes of the aircraft flight lies in the fact that the previous studies revealed that the disturbed airflow at the entrance of the compressor may lead to the occurrence of its unstable operating. This unstable work of the compressor causes the appearance of vibrations that are the most pronounced in the regimes with a high deviation from the horizontal flight.

The tests were performed in the winter period, with higher air density.

The changes of altitude and airspeed are given in Fig.2. At the same diagram the pitch angle of aircraft in climbing at altitude of $H_{i}=2500 \mathrm{~m}$ is given. The pitch angle in climbing was $10^{\circ}<\theta<15^{\circ}$.
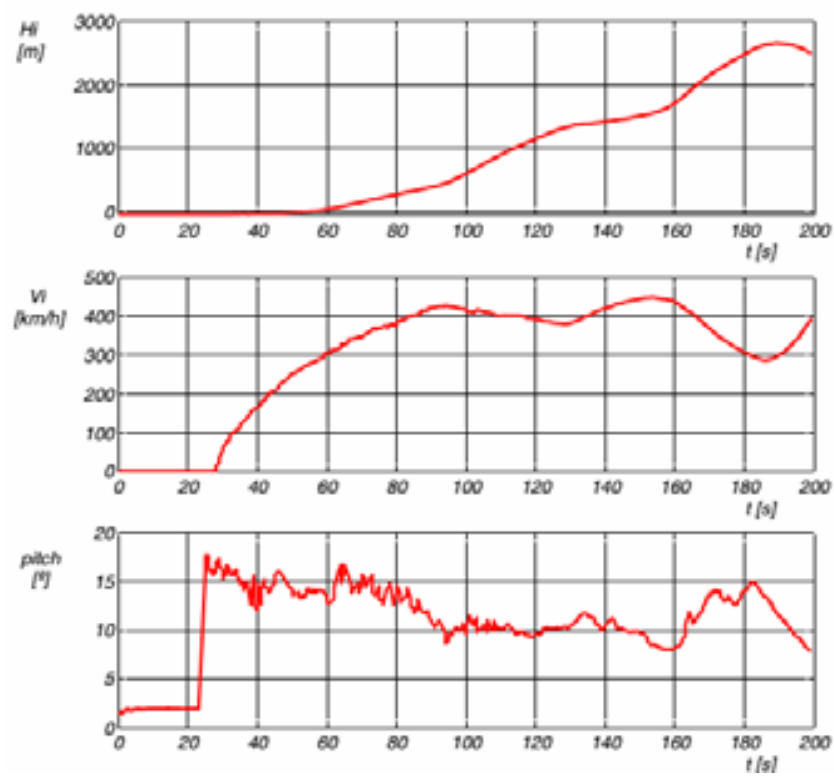

Figure 2. Parameters of flight in climb regime

The parameters of the horizontal flight at $H_{i}=2500 \mathrm{~m}$ are given in Fig.3. The maximum airspeed was achived at pitch angle of $\theta=0.75^{\circ}$.

The parameters of the climbing turn from altitude $H_{i}=2400 \mathrm{~m}$ up to $H_{i}=2800 \mathrm{~m}$ are given in Fig. 4 and 5 .

During the whole climbing turn $N_{z}$ was varying between $3,3<\mathrm{N}_{\mathrm{z}}<4,5 \mathrm{~g}$, with its maximum for pitch angle of $\theta=6.40^{\circ}$. 

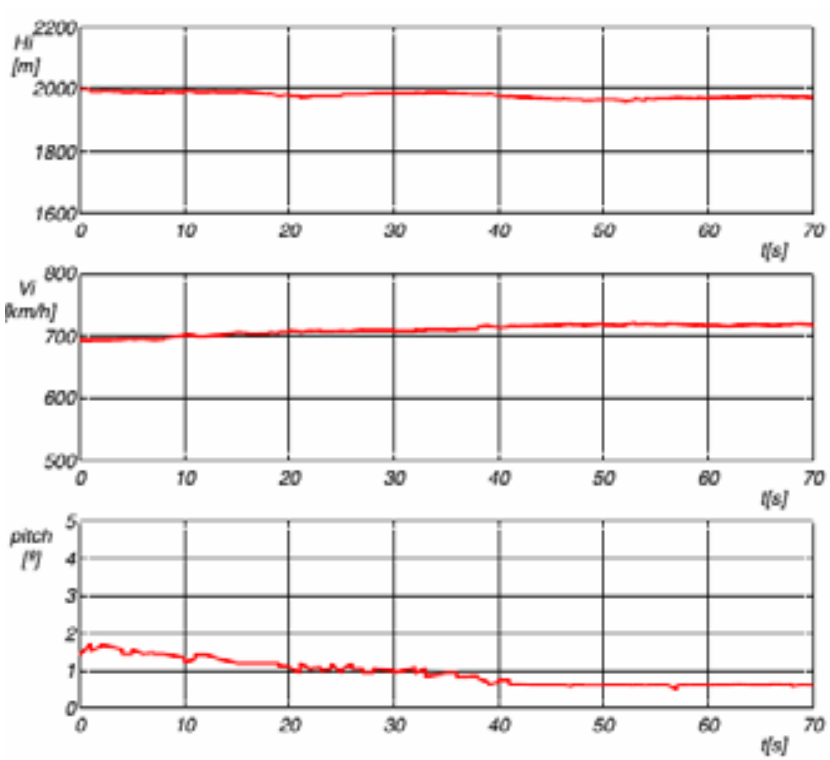

Figure 3. Parameters of flight in horizontal flight
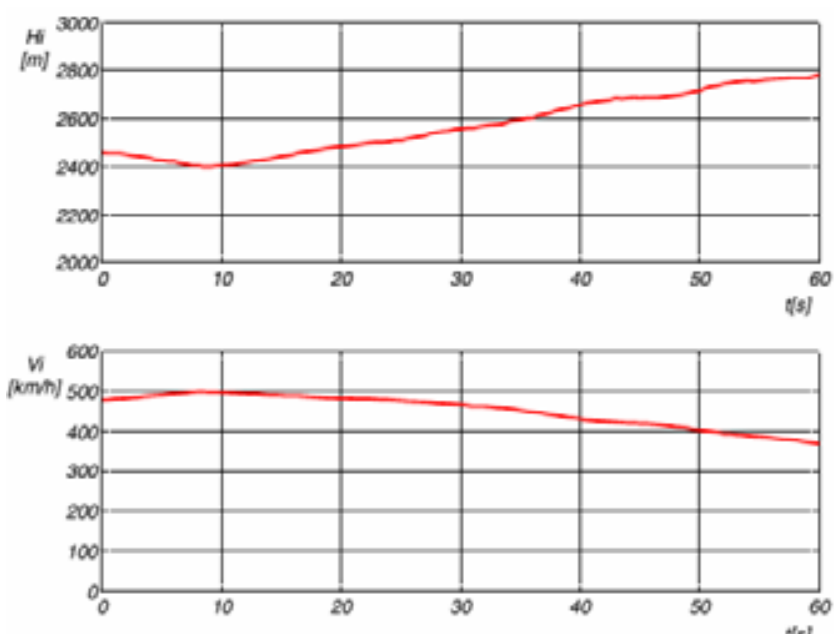

Figure 4. Parameters of the altitude and airspeed in climbing turn

\section{Discussion}

Based on the both flight regimes given in Figures 2-5 and results of the measurements, frequency vibration spectrums, in the first two stages of the compressor, were shown in Figures 6 and 7.
To show the measured vibration a linear scale was selected on both abscissa (X-axis) and ordinate (Y-axis), to quickly determine the most dominant vibration and their frequencies.

In order to estimate the intensity of vibration in the first stages of the compressor, in the radial direction during all phases of flight, Fig. 6 shows the frequency spectrum of vibration in the radial direction. Similarity, frequency spectrum of vibration in the tangential direction is shown in Fig.7.

The Figures 6 and 7 display the frequency vibration spectrums at $100 \%$ of engine power operation mode, in a range of $6000 \mathrm{~Hz}$ for both accelerometers mounted on the engine (Fig.1). The resonance frequency of the accelerometers bracket on the engine can be observed, and this band will appear in all diagrams which show the flight regimes data.
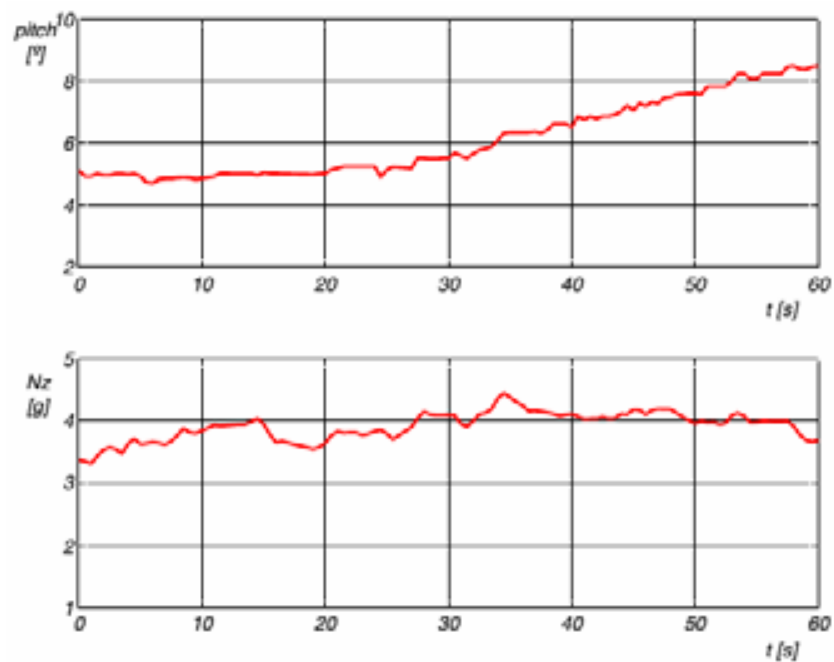

Figure 5. Parameters of the pitch and "g" loads in climbing turn

Based on the recorded data it can be seen that the pronounced vibrations occur at those frequencies which are equal to the multiple values of the fundamental frequency of the engine at $100 \%$ engine thrust. According to that, the largest vibrations occur in the first compressor stage, at the frequency of about $5520 \mathrm{~Hz}$, which matches with number of the first stage blades $(230 \mathrm{~Hz} \times 24)$. The second largest vibrations occur in the second stage of the compressor rotor and match with the frequency value of $5750 \mathrm{~Hz}(230 \mathrm{~Hz} \times 25)$, while the vibrations values of other stages are significantly less than the mentioned above.

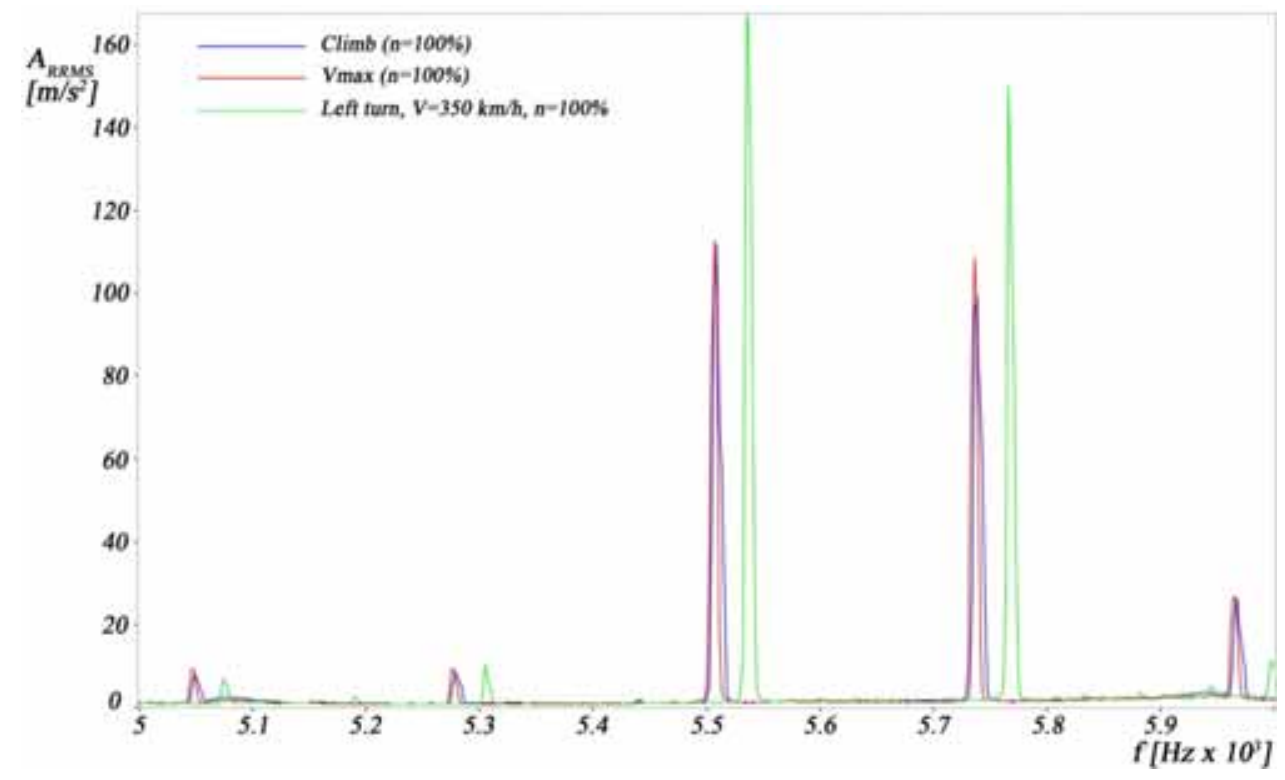

Figure 6. Averaged frequency vibration spectrums in the radial direction 


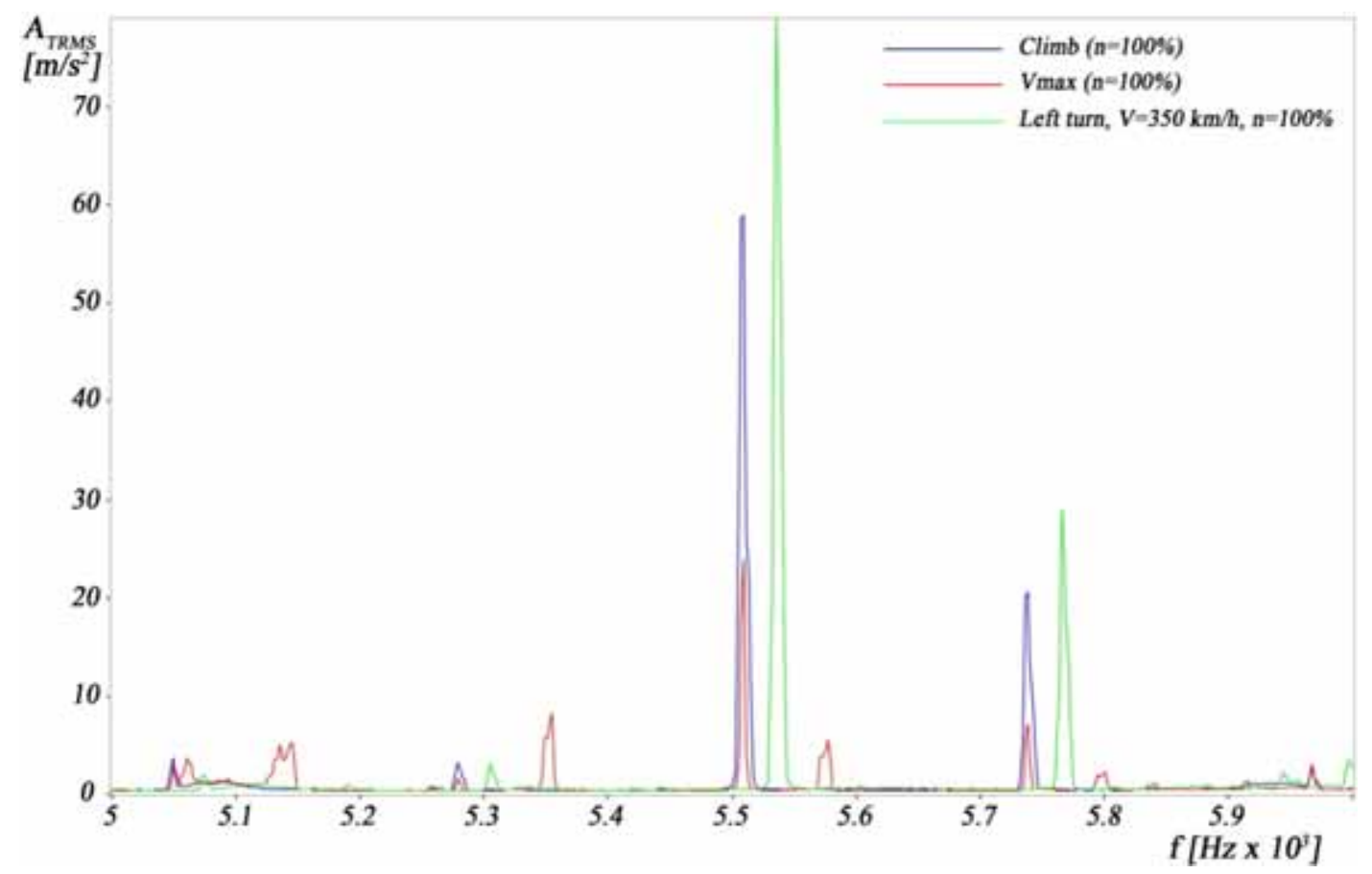

Figure 7. Averaged frequency vibration spectrums in the tangential direction

Particular attention should be paid to the climbing turn mode of flight which has much higher vibration levels than other two modes of flight, in both radial and tangential directions. Fig. 6 shows that for the frequency value of 5520 $\mathrm{Hz}$, the value of vibrations is $170 \mathrm{~m} / \mathrm{s}^{2}$ for the climbing turn regime and $115 \mathrm{~m} / \mathrm{s}^{2}$ for both regimes of horizontal flight and climbing. For the same frequency, in Fig.7 was shown the vibration value of $78 \mathrm{~m} / \mathrm{s}^{2}$ for climbing turn regime, $58 \mathrm{~m} / \mathrm{s}^{2}$ for the climbing, and $23 \mathrm{~m} / \mathrm{s}^{2}$ for the horizontal flight regime. These data suggest that far greater vibrations values occur in the radial than tangential direction.

\section{Conclusion}

Comparative experimental studies of the vibration level at jet aircraft have been carried out with a different aircraft attitude. This work contributes towards an explanation of the inlet flow field alteration related to the increase compressor loads.

Based on the carried out measurements and tests, we conclude that the disturbed airflow at the entrance of the compressor affects the occurrence of vibration in the compressor.

These vibrations occur as a result of separating air stream of the compressor blades at the high angle of attack, under the flight conditions when the uneven distribution of airflow through the twin inlet ducts exist. Comparing the vibration values, it can be seen that the increase of all vibration amplitudes occurs in the mode with a higher deviation from horizontal flight and axial airflow. In the turning mode, one of the two twin-intake air flow has a shaded position, which leads to disruption of the air flow in an inlet. Additionally, this disruption of the air flow through the inlet, leads to inequalities of the air flow fields at the entrance of the compressor and affects the occurrence of vibration in the tangential and radial direction.

The values of vibrations in the radial direction for the same flight regimes are significantly higher than in the tangential direction. This is in agreement with the stresses analyzed in this paper in section Stress on the axial-flow compressor blade and leads to a conclusion that the occurrence of vibration due to the disturbed air flow through the inlet, during the climbing turn, affects the increase in the stresses of the compressor blades.

This method has proved to be very successful for a good start position in the development of a permanent vibration monitoring system and can improve the maintenance according to the condition of aircraft and engines. Thus, a special attention should be paid to determination of damage parameters of the first stage compressor blades, as consequences of the greatest stresses which occur.

As a result of this work the monitoring of the aircraft flight during the exploitation may be recommended, especially in the case of sharp turns at full engine thrust, in terms of stresses and possible damage of the first stage compressor blades.

The illustrated methodology and measurement can be applied to all types of turbojet aircraft with the axial-flow compressor.

\section{References}

[1] KIM,J.H., CHOI,K.J., KIM,K.Y.: Aerodynamic analysis and optimization of a transonic axial compressor with casing grooves to improve operating stability, Aerospace Science and Technology, 2013, Vol.29, pp.81-91.

[2] GOURDAIN,N., BURGUBURU,S., LEBOEUF,F., MITON,H.: Numerical simulation of rotating stall in a subsonic compressor, Aerospace Science and Technology, 2006, Vol.10, pp.9-18.

[3] REID, C.: The Response of Axial Flow Compressor to Intake Flow Distortion, ASME Paper 69-DT-29, 1969.

[4] GHISU,T. at al.: Axial compressor response to inlet flow distortion by a CFD analysis, ASME TURBO EXPO Power for Land, Sea, \& Air,Vienna, Austria, 2004, 53846

[5] HAO,C., ZHU,F.,JIN,D., GUI,X.: Effect of blade sweep on inlet flow in axial Compressor cascades, Chinese Journal of Aeronautics, 2015, Vol.28, pp.103-111.

[6] LEWIS,W.E., WILLIAM,C.E., WILLIAM,P.R.: Effect of uneven airflow distribution to the twin inlets of an axial-flow turbojet engine, NACA, 1953.

[7] CURTIS,L., WALKER, JOSEPH,N., SIVO, EMMERT,T, JANSEN,S.: Effect of unequal air-flow distribution from twin inlet ducts on performance of an axial-flow turbojet engine, 1954, NACA.

[8] LU,H., CHEN,F., WAN,J., WANG,Z.: Flow Field Improvement by Bowed Stator Stages in a Compressor with Different Axial Gaps Under Near Stall Condition, Chinese Journal of Aeronautics, 2008, Vol.21, No.1, pp.215-222 
[9] SZCZEPANIK,R.: Analysis of 1st stage compressor rotor blade stress and vibration amplitudes in one-pass jet engine, Journal of KONES Powertrain and Transport, 2013, Vol.20, No.4, pp.441-449

[10] LI,C.P. et al.: Effects of axial spacing on compressor stalling characteristics, Journal of Engineering Thermophysics, 2006; 26(2): pp. $246-248$

[11] STUPAR,S., SIMONOVIĆ,A., JOVANOVIĆ,M.: Measurement and Analysis of Vibrations on the Helicopter Structure in Order to Detect
Defects of Operating Elements, Scientific Technical Review, ISSN 1820-0206, 2012,Vol.62, No.1, pp.58-63

[12] SKUBAČEVSKIJ,G.S.: Авиационные газотурбинные двигатели, Машиностроение, 1981, pp.206-249

\title{
Merenje i analiza vibracija aksijalnog kompresora izazvanih nestabilnim protokom vazduha kroz uvodnik tokom leta aviona
}

\begin{abstract}
U radu je prezentovan praktičan primer merenja i analize vibracija na prva dva stepena aksijalnog kompresora sa namerom da se proceni povezanost između poremećene ulazne struje vazduha i pojave otcepljenja strujnica od lopatica kompresora. Poremećenost ulazne struje vazduha je ispitivana tokom različitih režima leta aviona sa maksimalnim potiskom, pod pretpostavkom da postoji nesimetrično strujanje vazduha kroz dvostruki uvodnik i da ono ima uticaj na pojavu vibracija kompresora. Prikazano je merenje vibracija na avionu Galeb G-2 sa motorom Rolls Royce Viper Mk22-6 sa ciljem da se prepozna i definiše minimum neophodnih podataka koji bi ukazali na potencijalnu poremećenu struju vazduha kroz kompresor, kao posledicu nejednake raspodele vazdušne struje u uvodniku. Efikasnost ove metodologije merenja predstavljena je korišćenjem Furijeovih transformacija. Predložena metodologija merenja i analize može se sprovoditi na različitim tipovima aviona u cilju istraživanja pojave otcepljenja strujnica i pumpanja kompresora.
\end{abstract}

Ključne reči: avionski motor, mlazni motor, aksijalni kompresor, strujanje vazduha, vibracije, merenje vibracija, odvajanje struje, ispitivanje u letu.

\section{Измерение и анализ вибраций осевого компрессора, обусловленных нестабильным потоком воздуха через воздухозаборник самолёта во время полёта}

\begin{abstract}
Эта статья представляет собой практический пример измерения и анализа вибраций на первых двух этапах осевого компрессора с целью оценки связи нарушенного входного потока воздуха и отделения линии тока от лопаток компрессора. Нарушение входного потока воздуха было исследовано в различных режимах полёта самолёта с максимальной тягой, при условии, что существует несбалансированный поток воздуха через двойной воздухозаборник и что он оказывает влияние на возникновение вибрации компрессора. Показано измерение вибраций на самолёте Галеб G-2 (Чайка) с двигателем Rolls Royce Viper Mk22-6 для того, чтобы признать и определить минимум необходимых даных, которые указывают на возможность нарушенного потока воздуха через компрессор в результате неравномерного распределения потоков воздуха в воздухозаборнике. Эффективность этой методологии измерения представлена с помощью преобразований Фурье. Предложенная методология измерения и анализа может быть проведена на различных типах воздушных судов, с целью исследования феномена отделения линии тока и накачки компрессора.
\end{abstract}

Ключевые слова: авиадвигатель, реактивный двигатель, осевой компрессор, воздушный поток, вибрации, измерение вибраций, разделение потока, испытание в полёте.

\section{Mesurage et analyse des vibrations du compresseur axial provoquées par le courant instable de l'air par le tuyau d'arrivée pendant le vol d'avion}

\begin{abstract}
Ce papier présente un exemple pratique de mesurage et d'analyse des vibrations à deux premiers degrés du compresseur axial dans le but de faire l'estimation de la connexion entre deux courants d'air d'entrée perturbés et l'apparition de séparation des courants des lames du compresseur. La perturbation du courant d'air d'entrée a été examinée pendant les différents régimes du vol d'avion à la poussée maximale en supposant qu'il existe le courant d'air non symétrique à travers le double tuyau d'arrivée et que cela agit sur l'apparition des vibrations chez le compresseur. On a présenté les mesurages des vibrations pour l'avion Galeb G-2 équipé du moteur Rolls Royce Viper Mk 22-6 afin de reconnaître et de définir le minimum des données nécessaires pour la détection du courant d'air dans le tuyau d'arrivée. L'efficacité de cette méthodologie de mesurage a été représentée par l'emploi des transformations de Fourier. La méthodologie proposée de mesurage et d'analyse peut s'appliquer chez les différents types d'avion dans le but d'examiner l'apparition de séparation des courants et le pompage du compresseur.
\end{abstract}

